\title{
Environmental Justice and the Roma Settlements of Eastern Slovakia: Entitlements, Land and the Environmental Risks*
}

\author{
RICHARD FILČÁK** \\ Slovak Academy of Sciences, Bratislava***
}

\begin{abstract}
Exposure of the Roma ethnic minority to social exclusion, segregation, and racial discrimination is well documented in the literature. How these tendencies are reflected in the access to environmental benefits and exposure to environmental risks in the majority and the minority populations is the subject of this article. Using a comparative evaluation and the concept of environmental justice the author analyses the social processes and factors that contribute to differentiated distribution of risks/benefits. Based on a survey of 30 randomly selected settlements and comparative case study analyses the author maps inequalities, identifies the location of a Roma settlement as a strong factor leading to various forms of environmental (in)justice, and subjects the settlement locations to an entitlement analysis (as developed by Amartya Sen). Particular attention is paid to defining and understanding entitlements and how they govern access to land and thus influence the living conditions and well-being of different individuals and groups. Entitlements and the entitlement-based control of resources are discussed here as a dynamic process, the different economic and social factors behind which are identified and analysed to deconstruct the processes that lead to environmental (in)justice. The article concludes with a description of trends and a discussion of the need to re-think our definitions and understanding of the role of entitlements in relation to the distribution of environmental benefits and risks.
\end{abstract}

Keywords: environmental justice, entitlement analysis, Roma ethnic minority, land use, environmental sociology, Slovakia

Sociologický časopis/Czech Sociological Review, 2012, Vol. 48, No. 3: 537-562

In June 2010 more than 120 inhabitants of the village of Nižny Tvarožec were forced to leave their homes because of a river that was regularly flooding their homes. Around 500 people in Rudňany-Pätoracké of Eastern Slovakia live in a zone susceptible to landslides or surrounded by toxic waste from mining activities. All these people belong to the Roma ethnic minority. The village of Jarovnice

* The present version of this article has greatly benefited from comments by Petr Jehlička, Marek Skovajsa, and anonymous reviewers.

** Direct all correspondence to: Richard Filčák, Institute for Forecasting of the Slovak Academy of Sciences, Šancová 56, Bratislava, Slovak Republic, e-mail: richard.filcak@ savba.sk.

*** This article was prepared as part of work on project VEGA 2/0032/11.

(C) Sociologický ústav AV ČR, v.v.i., Praha 2012 
became renowned in Slovakia after a disastrous flood in the summer of 1998 left 47 dead. Of the 47 victims, 45 were Roma (42 were from the shantytown in Jarovnice). These figures require closer investigation. Roma are not the only victims of floods or adverse environmental impacts, yet why are Roma so highly represented among them?

The negative impacts of industrial production and development do not affect everyone in society evenly. Environmental risks and the distribution of adverse effects of development are more likely to affect those who do not possess adequate resources for their own protection or are discriminated against because of their origin. As Beck [1999: 7] claims: 'the first law of environmental risk ispollution follows the poor'. For those poor who are also discriminated against because of their ethnic affiliation and already experience social exclusion, the environment may represent yet another form of discrimination: discrimination for which we may use the analytical framework of environmental justice.

We look for answers to the question of why some people (or groups) are worse off than others (i.e. their neighbours) when it comes to the distribution of environmental benefits and risks, and why the risks of the areas in which they are settled are unequal. This inequality in the distribution of environmental benefits (i.e. clean water and a safe environment) and risks (i.e. the risk of flooding or exposure to pollution) in the Slovak or perhaps more broadly the Central and Eastern European (CEE) context is certainly not confined to the Roma. They are, however, in many cases in situations where we can see clear and unambiguous inequalities and can map and analyse this distribution. The main source of data for this article is field research carried out among Roma communities in Eastern Slovakia, which began in 2002 and is still ongoing.

Many books, articles and reports have been written on the roots of segregationist tendencies, prejudices and racial discrimination against ethnic minorities [Mann 1992; Guy 2001; UNDP 2002; World Band 2002, 2003; Scheffel 2005; EC 2011]. Nevertheless, the problem of the distribution of environmental benefits and risks is a comparatively new topic in Central and Eastern Europe (but see Steger et al. [2007]; Antypas, Filčák and Steger [2008]; Steger and Filčák [2008]; Harper, Steger and Filčák [2009]; Filčák and Skobla [2011]).

This article builds on field research that focused on two inter-related questions: Can the situation in some Roma settlements be described as environmental (in)justice? If so, what are the forms and scope of unequal treatment, and what are the impacts on the affected communities? By applying an environmental justice framework, this article focuses on the role that entitlements play in the distribution of environmental benefits and exposure to risks.

The key issue is identified as the location of the settlements. Whoever owns land or has power and control over land distribution may heavily influence the spatial options for settlement of the weaker and poorer members of the community. Here, we may therefore see how the distribution of entitlements and control sometimes leads to the creation of environmental (in)justice. In other words, in- 
justice can be the outcome of a distribution shaped by economic interests, competition over resources, ethnic prejudices, and other social factors.

From the entitlement theory and entitlements analyses developed by Amartya Sen [1981, 1984, 1999] it is apparent that land distribution is not just about the problem of scarcity of resources (i.e. clean areas for settlement and houses construction). It can also raise the issues of who has access and entitlement to use these resources, who decides on such access, and on what criteria and interests such decisions are based. As will be shown below, we need to go beyond Sen's original formulation of entitlements built on individuals' legal ownership of alienable commodities and focus on weaker claims on resources, formal and informal power, and the role of stakeholders in the decision-making process. Last but not least, entitlements can also be seen in the context of duties and responsibility.

\section{Environmental justice and entitlements}

The environmental justice analytical framework was originally developed in the United States and broadened in the UK. The framework as it emerged in the United States is strongly linked to the environmental justice movement. As Kurian [2000: 32] observes: 'They [environmental justice movements] seek to bridge the concern for social justice and equity with resource management and environmental policy concerns.' Pointing to a particular date or event that launched the environmental justice movement is impossible, as the movement grew organically out of dozens, even hundreds, of local struggles and events and out of a variety of social movements [Cole and Foster 2000; Shelton 1999].

Nevertheless, there are several cases that are often cited as milestones: the Houston Northwood Manor protest against sanitary landfill (1978); the protest in Warren County in North Carolina by African Americans against a toxic waste dump (1982); and Triana in Alabama, where a tiny black community was contaminated with DDT from the Redstone Arsenal Army base (1983). These and other cases are often labelled as watershed events in the protest movement seeking to address inequalities in the distribution of negative impacts of environmentally damaging activities.

The movement started with the demand for equality in the distribution of environmental harm. Yet, alongside inequality, we must speak about recognition of the diversity of the participants and experiences in the environmental justice movement. This is often not done, and theorists and practitioners often highlight either the former or the latter aspect [Schlosberg 1999].

The 1987 breakthrough study Toxic Waste and Race concluded that 'race was the central determining factor in the distribution of chemical hazard exposure in the United States' [Bowen and Wells 2002: 14]. However, it also concluded that class played an important role. In 1990 Robert D. Bullard published Dumping in 
Dixie: Race, Class, and Environmental Quality as the first textbook on environmental justice. Elliot, Lowe and Kleindorfer [2004] found that low levels of income and education are strongly correlated with the location of high-risk polluting industries. Ethnicity may also play a strong role in this distribution.

Contrary to the US situation, cases of community struggles for equal treatment in the distribution of environmental harm in the UK are led by professional environmental organisations with highly educated staff and international expertise. In this perspective we may label the UK approach more 'top-down' than the various environmental justice protests at the grassroots level in the United States. Nevertheless, the results of studies conducted by Friends of the Earth in the United Kingdom have confirmed the US experience that communities lacking economic and political power are the most likely to be targeted for dumping waste and pollution [Stephens, Bullock and Scott 2001; Scandrett 2000; Agyeman 2002]. ${ }^{1}$

Environmental justice is generally defined as the fair treatment and recognition of all the stakeholders in the processes involved in the distribution of environmental benefits and risks, while the distribution itself is done in a way that no social or ethnic group bears an unequal share of environmental risk or is blocked from accessing environmental benefits [UCCCRJ 1991; EPA 1996]. Participants of the first workshop on Improving Environmental Justice in Central and Eastern Europe developed the following definition of environmental justice in December 2004: 'A condition of environmental justice exists when environmental risks and hazards, and investments and benefits, are equally distributed, without direct or indirect discrimination, at all jurisdictional levels. It also requires that access to environmental investments, benefits, and natural resources are equally distributed, and that access to information, participation in decision making, and access to justice in environment-related matters are enjoyed by all. ${ }^{2}$ In this approach the focus is on environmental justice as a form of social distributive justice among human beings at the present time and within ecological limits. ${ }^{3}$ In addition to the distributional aspect it focuses on procedures associated with the allocation of environmental benefits and risks. In other words, it means identifying real outcomes of the distribution (i.e. 'who gets what'); and real processes (i.e. 'how it happened').

The framework originally developed in the United States provides an important point of departure for studying the distribution of the environmental

\footnotetext{
1 See, for instance, Friends of the Earth England, Wales and Northern Ireland's 'Pollution Injustice' campaign and Friends of the Earth Scotland's 'Campaign for Environmental Justice'.

${ }^{2}$ For more information on the Central and Eastern European initiatives, see Pellow, Steger and McLain [2005] or Steger et al. [2007].

3 There are different possible perspectives: we can look at the distribution from a global perspective or from the perspective of the nation-state, region, or settlement. We may consider among stakeholders not only people exposed to the unequal impact of industrial pollution, but also future unborn generations or non-human beings.
} 
benefits and adverse impacts in the countries of Central and Eastern Europe. Yet, as Elvers, Gross and Heinrich [2008] suggest, the realities of most European societies differ from those in the United States, where we find a rather narrow understanding of environmental justice, restricted to a certain group or ethnic minority (or people of colour). The important challenge is to outline a concept of environmental justice as an inherent feature of controversial decision processes. These may relate to any kind of regulation perceived to affect the environments of heterogeneous stakeholders. [Elvers, Gross and Heinrich 2008: 836].

While we agree that there is some justification for this call to broaden and adjust the approach in Europe, there are possible exemptions for immigrants and ethnic minorities, where an environmental justice framed around ethnic or class factors and equality has solid ground. One of them is the Roma ethnic minority, where a correlation between class and/or ethnicity and exposure to environmental risks has recently been identified and described [Steger et al. 2007; Harper, Steger and Filčák 2009; Filčák 2010, 2012].

Today, many Roma settlements are found on the outskirts of villages, separated from the majority of the population by roads, railways, or other barriers, disconnected from water pipelines and sewage treatment facilities, and close to landfills or in areas regularly subject to flooding. The location of these settlements confirms experience from other countries: access to natural resources and exposure to environmental risks are not equally distributed and class and/or ethnic affiliation play an important role [Bullard 1990; Bryant and Mohai 1998; Bullard and Johnson 2000; Pellow 2002; Walker et al. 2003; Schlosberg 2004]. In other words, environmental risks and the distribution of adverse effects have a tendency to be imposed more on those who do not possess adequate resources for their own protection or are discriminated against because of their ethnic origin.

This research indicates that the differentiated exposure to environmental risks in the Roma and neighbouring non-Roma communities results from ethnic discrimination in the distribution (i.e. 'who gets what' is influenced by the perceived 'inferiority' of the Roma by the majority); and real processes (i.e. 'how it happened' reflects the relative strength and weakness of different social actors).

In analysing identified cases of environmental (in)justice this article focuses on the question of the location of settlements. Why are the identified Roma settlements located in places that limit their access to resources and exposing them to adverse environmental impacts? What were or are the distributional and procedural aspects of land allocation? The article documents and analyses how the location of Roma settlements is related to the distribution and control of entitlements. As we discuss, the location does not predominantly depend on the type of land ownership (private or collective) or on the form of governance, ${ }^{4}$ but rather on the broader economic and social interests of those in control.

${ }_{4}^{4}$ This does not mean that different types of governance do not provide different opportunities and mechanisms for weakening or strengthening control over entitlements. 
Amartya Sen [1981, 1984, 1999] identified entitlements as the basic precondition for the expansion of capabilities and he seems to have been the first to pursue their analysis. He is interested in how people gain and lose control over resources and his initial subject of research was famines and access to food. Based on this study he notes that 'starvation is the characteristic of some people not having enough food to eat. It is not the characteristic of there being not enough food to eat. While the latter can be a cause of the former, it is but one of many possible causes' [Sen 1981: 18]. In this sense, the lack of benefits from natural resources is not always a problem of scarcity of resources (i.e. clean areas for settlement), but can also be a problem of who controls the entitlement to use these resources. Entitlement rights may govern access to natural resources and thus influence the capabilities of different individuals and groups and their well-being.

Amartya Sen [1984: 497] defines entitlements as the set of alternative commodity bundles that a person can command in a society using the totality of rights and opportunities that he or she faces. This understanding of entitlements is broad and encompasses numerous aspects. One can possess entitlement to certain resources through ownership (e.g. inheritance, production, trade), or through rights legitimised by laws and rules (e.g. nominated or elected representatives with decision-making power). However, entitlements may also derive from unwritten rules of management of common pool resources.

In his original formulation Sen was only concerned with legal ownership by individuals of alienable commodities. He ignored the possibility of weaker claims over resources, such as access and usufruct rights, as well as contexts where property rights are exercised institutionally, such as common, rather than individual property regimes [Devereux 2001: 253]. Yet, as the follow up research revealed (and our survey of the Roma communities confirms), these are of principal importance for the analyses. Sen further claims that entitlements derive from legal rights rather than morality, or human rights and should therefore be treated as a descriptive, rather than a normative concept [Sen 1984: 166]. Yet, even if entitlements as such are not a normative concept, the ways in which people and social groups approach their distribution are to a significant degree (at least in our examples) dependent on morals, values, and perceptions. In addition, there are (equally if not even more important) economic interests that play a crucial role in the distribution.

Ownership and formal rules are an important part of the puzzle, but equally important is to take into account other social processes framing the decision and its outcomes. An extended entitlements approach therefore sees entitlements as the outcome of negotiations among social actors, involving power relationships and debates over meaning, rather than as simply the result of fixed, moral rules encoded in law [Leach, Mearns and Scoones 1997: 23].

Many rights to natural resources are outcomes of complicated social processes at the local level and are not directly based on legally binding rules, writ- 
ten agreements or enforceable procedures. Alternatively, social networks and decision-making power can be viewed as being based on social membership. As Leach, Mearns and Scoones [1997, 1999] note, resource claims are often contested, and within existing power structures some actors' claims are likely to prevail over those of others. Socially determined entitlements are more dynamic and liquid and-crucially for entitlement analysis-less amenable to specification at the individual level than market-determined entitlements.

Building on the extended entitlements approach, an entitlement is defined here as the state or condition of having a guarantee of access to benefits. Or more specifically, it is the right to develop certain land for a desired use. This could be formal, specified by law or contract, but in social reality there are also informal rules that govern the management of natural resources and the utilisation of associated benefits in a community (e.g. unwritten decisions, traditions, or habits).

We need to see entitlements not just as a part of the problem, but also as a part of the solution. We cannot simply address environmental justice through a reallocation of entitlements and rights to individuals; we need to see the broader perspective that encompasses respect for others, obligations, duties, and responsibility. Mark J. Smith and Piya Pangsapa [2008] call this 'circuits of justice', or, in other words, spaces in which new configurations of entitlements and obligations are constructed through discourses and accepted praxis.

Entitlements are a strong driver of community development: they are assets that help communities and individuals. Those who control the resources in a village or town enhance their capabilities and social networks. Those who are excluded from these entitlements are restricted in how much they may develop their capabilities and may remain in a weaker position in society.

The unequal distribution of environmental benefits and risks needs to be analysed within a framework of deeper social processes and mechanisms causing the differentiated treatment of different people or social groups. The focus is on the question of 'why' these trends arise. Although non-Roma and Roma share the same space, their resources and power are not equal and the stronger group takes over local governance structures, thus dominating the distribution of entitlements. When it comes to decision making at a local level, the stronger group (i.e. non-Roma) may mobilise its economic power and social capital and make (or influence) decisions to benefit themselves. This leads to the development of a privatised, exclusionist style of governance that fails to reflect diverse values and interests, while proving discriminatory to others.

Entitlements are dynamic and change over time. Roma are not 'passive objects' but rather active subjects who aspire (or potentially aspire) to increase their share of resources. Decentralisation and local elections introduced in the 1990s have become the most important mechanisms for challenging the exclusionist style of governance and changing entitlements through increasingly visible political mobilisation and local elections. Roma are becoming more and more able 
to overcome internal fragmentation (especially in villages) and unite for local councils and mayoral elections. ${ }^{5}$ The European Union (EU) and nation-state policy framework further entitle marginalised people and communities with antidiscrimination measures (e.g. a court decision prohibiting the new construction of housing for Roma in isolated locations, which will be discussed below). In this article we discuss how these and other factors and trends have been changing entitlement distribution and control in cases where there are two groups competing over the same resources, as is the case in villages in eastern Slovakia inhabited by Roma and non-Roma.

\section{Data analysis}

The Roma ethnic minority was studied in field research on environmental justice in Slovakia between 2005 and 2009. The research was inspired and motivated by the conditions identified in the literature: the widespread patterns of social exclusion and spatial segregation of Roma settlements from the main villages [Guy 2001; UNDP 2002; Scheffel 2005; Matlovič 2005; Hurrle 2005]. The aim was to explore how this social and spatial exclusion of the Roma population is reflected in access to environmental benefits and exposure to adverse impacts, to document specific forms of environmental (in)justice, and to analyse its origin, roots, and implications.

The first goal of the field research was to assess of the quality of the environment and exposure to environmental risks. Two groups of research questions were posed at the beginning of the research: Can the situation in some of the Roma settlements be described as environmental (in)justice? If so, what are the forms and scope of the unequal treatment, and what are the impacts on the affected communities? This required making a comparative qualitative evaluation of the situation, conditions, and discrepancies between the majority and minority environmental living space. The second (related) goal was to map the land ownership and entitlements over the space in which the Roma settlements are located. What is the entitlement distribution, how does it relate to the ownership pattern and what were and are the social processes associated with the unequal distribution of environmental benefits and harms?

The data presented here are based on the outcomes of regional research that was designed to provide a snapshot overview of the situation of Roma settlements in the selected eastern region of the Slovak Republic. ${ }^{6}$ In total, 30 settlements (out

\footnotetext{
${ }^{5}$ See, for instance, articles and statistics issued by the Roma Press Agency (RPA) available at: http://www.mecem.sk/rpa/?id=search\&lang=slovak\&show=22036, or http://www. mecem.sk/rpa/?id=local\&show $=20296$.

${ }^{6}$ Eastern Slovakia is the region with the highest concentration of Roma settlements in the country.
} 
Figure 1. Geographical distribution of the 30 Roma settlements included in the regional research

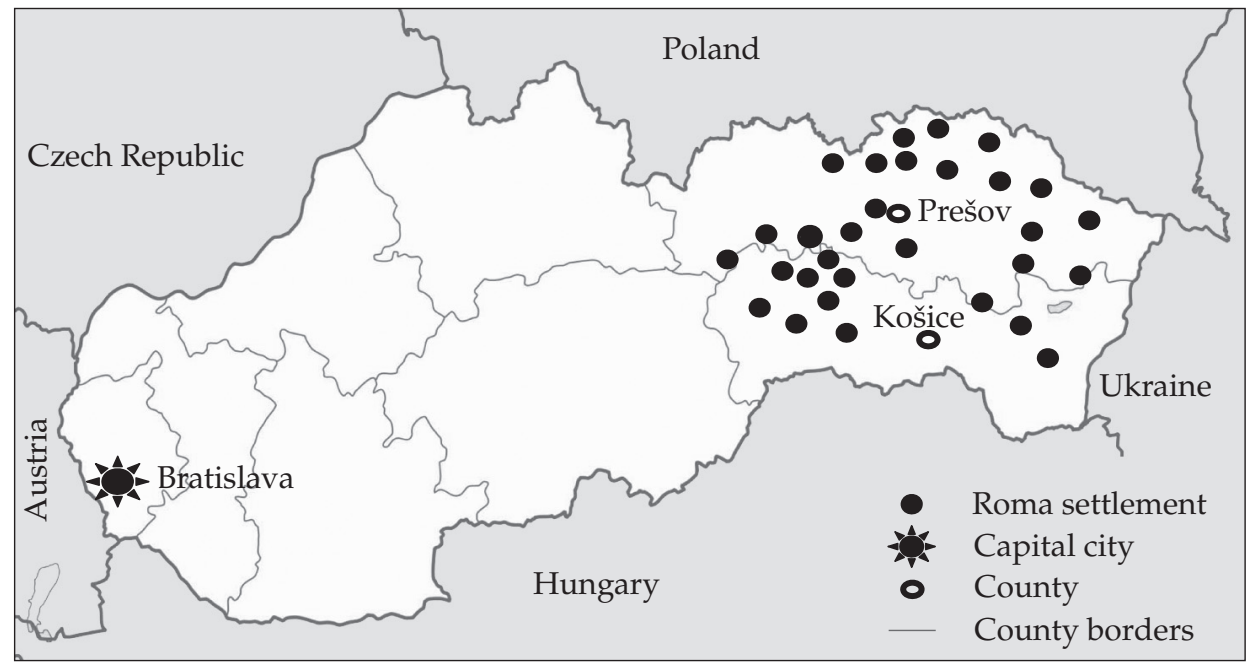

Source: Wikimedia Commons and the author.

of the 281 settlements identified) were randomly selected to be included in the research sample. ${ }^{7}$ To generate this set of random numbers, the research randomiser developed by the Social Psychology Network was used. ${ }^{8}$ Where there was more than one Roma settlement in a village, the biggest one was selected.

For the purpose of sampling, settlements concentrated in central parts of the town were omitted for the following reasons: (1) these settlements do not usually possess clear boundaries between Roma and non-Roma dwellings, and (2) it is hard to find any differences in the distribution of environmental benefits and risks. The focus is on settlements spatially segregated from the town or village by distance, by a natural barrier, such as a stream or forest, or by some other barrier, such as a railway track or road. The settlements in the sample belong administratively to two eastern Slovakian counties Prešov and Košice (see Figure 1 for the geographical distribution and Figure 3 for the names of the settlements).

\footnotetext{
7 The settlement numbers are based on a 2004 survey and the Atlas of Roma communities developed by the SPACE Foundation and the Institute for Public Affairs Bratislava, available at: http://www.romovia.vlada.gov.sk/3553/atlas-romskych-komunit-2004.php; or OPSGRC 2005 for more information.

8 The random numbers generator of the Social Psychology Network is available at: http:// www.randomizer.org/index.htm. This is a service offered to students and researchers interested in conducting random assignment and random sampling.
} 
Qualitative and quantitative data were collected and analysed for the research. Quantitative data were first collected from central authorities (i.e. the Ministry of the Environment, the Ministry of Construction and Regional Development, the Central Bureau of Statistics, and the Office of the Plenipotentiary of the Government for Roma Communities). These data were triangulated during field research with local authorities and NGOs.

Rapid Rural Appraisal (RRA) ${ }^{9}$ was used as the field research methodology. This involves a series of techniques for quick research that are aimed at generating results of less apparent precision but greater evidential value than classic quantitative survey techniques [Chambers 1994; Dunn 1994]. The research builds on a rapid on-site evaluation in each of the selected locations. The approach uses multiple methods, including archival research on the history of the settlements, a review of secondary sources, interviews with local stakeholders (i.e. mayors, NGOs, Roma leaders), and direct participant observation (i.e. water collection, waste management, local planning), foot transects, familiarisation, participation in activities, scoring and ranking, and rapid report writing in the field..$^{10}$ The method allows for the use of short simple questionnaires towards the end of the data collection process or, as in this case, a checklist, which was used to make a comparative evaluation of the Roma and non-Roma parts of the villages. Basic facts were sought on the distribution of benefits and harms between the majority and minority. At the end, triangulation was used to increase the validity of the data.

Environmental qualities were assessed relatively and Roma settlements were compared to a non-Roma part of the nearby village. We asked, how is an absolute criterion (e.g. the probability of floods or excessive pollution) reflected in local distribution and the level of exposure? Is there any difference in relative access to water and a clean environment or in exposure to environmental threats? The aim was to look for a particular variation in access and exposure to risk. The research was not focused on a comparative evaluation of variables, scope and impacts in different cases, but rather on an analysis of the social processes that lead to differentiated access and exposure at the local level.

Out of the 30 settlements, only seven cases indicated that access to natural resources and exposure to environmental threats for the Roma and non-Roma people was equal (Figure 2). The most widespread inequality is in access to potable water, where as many as 16 settlements are in a comparatively worse situation than their majority counterparts. In two cases, higher exposure to contamination from pollution was found, and in two cases unequal risk of floods was identified. In three cases there was cumulative exposure to more than one stressor (exposure to floods and unequal access to water).

\footnotetext{
${ }^{9}$ It need not necessarily be rural or rapid [Chambers 1994; Dunn 1994].

${ }^{10}$ See, for instance, A Guide for Field Projects on Adaptive Strategies. Available at: http:// www.iisd.org/casl/caslguide/rapidruralappraisal.htm.
} 
Figure 2. Comparative evaluation-higher exposure to risk or worse access to environmental resources in the Roma settlements compared to their non-Roma neighbourhood ( 30 settlements)

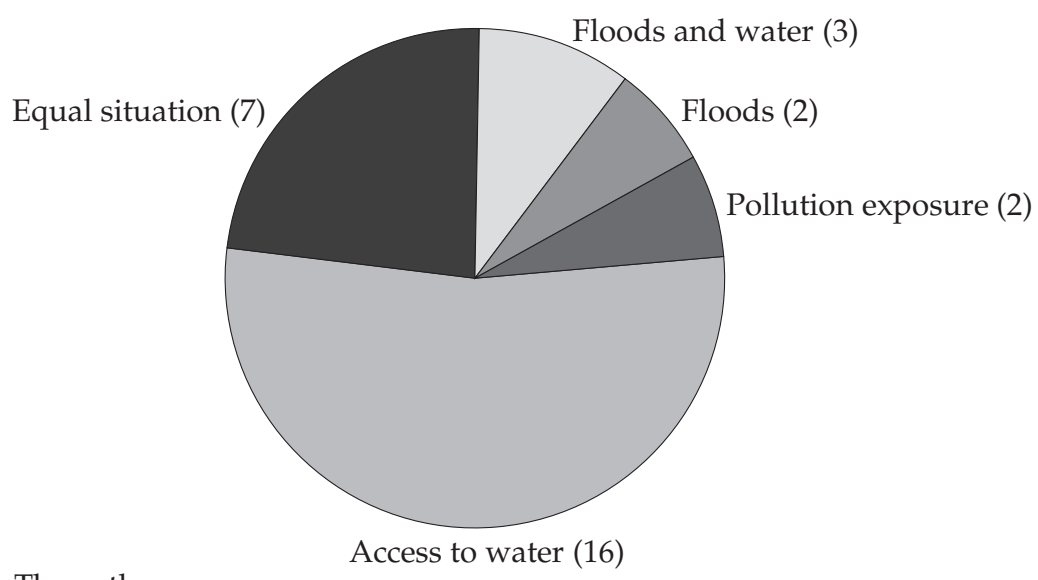

Source: The author.

The three areas, or patterns, where differentiated exposure and access were documented are: (1) exposure to floods, (2) exposure to industrial pollution, and (3) access to water and sanitation. ${ }^{11}$

(1) Exposure to floods: Exposure to floods is more likely in the case of Roma shantytowns segregated from the main villages. In some cases recent disasters have prompted the authorities to adopt anti-flood measures. This is, for example, the case in Uzovske Peklany, where, after disastrous floods in 1998, the municipality deepened the river bed. In four other villages included in the research sample (Nižný Tvarožec, Petrová, Markovce, and Chminianske Jakubovany), limited measures were adopted to address this danger. The floods of 2010 substantially impacted most of them. Results of the regional research on flood risks indicate that in at least five villages out of the 30, there was a higher risk of floods in the Roma settlements, than in the main village. ${ }^{12}$ There was no village examined in which non-Roma were more exposed to floods than Roma.

(2) Exposure to industrial pollution: A direct link between industrial production and unequal exposure to emissions was identified in the case of the Roma set-

\footnotetext{
${ }^{11}$ For instance, a study and report titled Environmental Quality and Social Deprivation, commissioned by the Environmental Agency of the UK [Walker et al. 2003], came to the conclusion that the three main areas of environmental inequality and social deprivation in Britain are (1) flood hazard, (2) integrated pollution control sites and (3) air quality.

12 Three settlements (out of these five) have the combined problem of a flood risk and unequal access to water.
} 
tlement in Krompachy, which is also home to non-Roma people. The class factor (besides ethnicity) can also be identified as playing an important role in this case.

This settlement is located at the foot of a hill, behind a smelting factory and under its chimneys. Most of the inhabitants are impoverished former workers from the nearby factory. The locality is spatially segregated from the town by a road and stream and four blocks of apartments were originally built there for the factory's workers. The factory's need for an unskilled workforce attracted Roma from surrounding areas and soon they formed a settlement surrounding the blocks of apartments. Except for a few families, the non-Roma inhabitants of the apartments gradually left. The second identified case is Trebišov and the meat processing factory that is located close to a Roma neighbourhood/settlement.

(3) Access to water and sanitation: There is a clear discriminatory pattern of unequal treatment concerning access to water and sanitation. On the micro level of communities, only 11 Roma settlements (out of the sample of 30 villages) have the same access to water as non-Roma. ${ }^{13}$ The usual situation is that the infrastructure (i.e. pipelines) connects to lines in the non-Roma community, whereas Roma are not connected to the networks. This situation is caused by multiple factors: Roma houses are often illegally built; the number of houses has grown significantly in recent decades (in some cases after the construction of pipelines); and Roma are simply not able to co-finance their construction.

The second goal of the field research was an entitlement analysis. We had two objectives: first, mapping land ownership in Roma settlements, ${ }^{14}$ and second, tracking land ownership history and dynamics over time. We were interested in the evolution of entitlements over the space in which the Roma settlements are located. We also wanted to understand the present situation and identify any trends.

Owing to an extremely complicated ownership structure and a lack of documentation it was impossible to evaluate ownership of the land in percentage terms or size, so the research focused on the ownership typology. Daniel Bromley [1989] identifies four main possible resource regimes: common property, private property, state property, and open access [Bromley 1989: 871]. With the exception of the last one we find these also in places where Roma have built their settlements:

- Common property: land in the possession and under the control of the municipalities;

- Private property: land owned by private legal (e.g. a forest association) or physical entities, sometimes by unknown owners;

- State property: land in the possession of the state and managed by its authorities.

${ }^{13}$ In 16 cases there is unequal access to water, and in another 3 cases there is the problem of unequal access to water and unequal exposure to floods.

${ }^{14}$ Almost all non-Roma houses are built on land owned by the owner of the house. 
Figure 3. Land ownership in 30 selected Roma settlements

\begin{tabular}{|c|c|c|c|c|c|c|}
\hline & Roma & Unknown & $\begin{array}{l}\text { Munici- } \\
\text { pality }\end{array}$ & $\begin{array}{l}\text { Non- } \\
\text { Roma }\end{array}$ & $\begin{array}{l}\text { Forest as- } \\
\text { sociation }\end{array}$ & $\begin{array}{c}\text { State } \\
\text { property }\end{array}$ \\
\hline Jánovce & & & & $\mathrm{x}$ & & \\
\hline Spišské Vlachy & $x$ & & & & & \\
\hline Zbudske Dlhé & $x$ & $x$ & $x$ & & & \\
\hline Uzovske Pekl’any & & & & & $x$ & \\
\hline Dvorníky-Včeláre & $x$ & $x$ & & & & \\
\hline Humenné-Podskalka & $x$ & & $x$ & & & \\
\hline Helcmanovce & $x$ & & & & & \\
\hline Bardejov-Dlhá lúka & & & $x$ & & & \\
\hline Rokytov & & & $x$ & & & \\
\hline Mníšek nad Hnilcom & $x$ & & $x$ & & & \\
\hline Zborov & & $x$ & & & & \\
\hline Petrová & $x$ & $x$ & $x$ & $x$ & & $x$ \\
\hline Lenártov & $x$ & $x$ & & & & \\
\hline Krompachy & $\mathrm{x}$ & $x$ & $x$ & $x$ & & \\
\hline Hažín & & & & $x$ & & \\
\hline Trebišov & $x$ & & $x$ & & & \\
\hline Spišské Bystré & & & & & $x$ & \\
\hline Medzilaborce - Palota & $x$ & & $x$ & & & \\
\hline Nižný Tvarožec & & $x$ & & & & \\
\hline Spišský Hrhov & $x$ & & & $x$ & & \\
\hline Chminianske Jakubovany & & & & $x$ & & \\
\hline Markušovce & $x$ & & $x$ & $x$ & & \\
\hline Bystrany & & & $x$ & $x$ & & \\
\hline Sečovce & $x$ & $x$ & $x$ & & & \\
\hline Markovce & & & $x$ & & & \\
\hline Bystré & $x$ & & & & & \\
\hline Nižná Jablonka & $x$ & & & & & \\
\hline Snina & $x$ & & $x$ & & & \\
\hline Trhovište & $x$ & & $x$ & & & \\
\hline Nižná Slaná & & & & $x$ & & \\
\hline
\end{tabular}

Source: The author. 
Figure 3 summarises different types of ownership of land in Roma dwellings and their occurrence (i.e. in how many of the 30 settlements is this type represented). The most common situation in the settlements is a complicated mixture of private land owned by Roma, non-Roma, municipalities, forest associations, or land belonging to unknown owners. It nevertheless provides a very interesting picture of the ownership landscape.

State ownership actually plays a marginal role; in only one case (Petrová) is some of the land in a settlement owned by the State Property Fund. Roma are the owners of at least some part of the land their settlements are on in only 18 cases. In 12 cases they do not possess any property rights over the land on which they live.

In Spišské Vlachy, Bystré, Helcmanovce and Nižná Jablonka the Roma are the owners of all the land in their settlements. More typically, houses built on Roma-owned land ${ }^{15}$ were later joined by a growing number of shelters as the communities grew in size. These are located on land close to properties with various types of ownership. Other settlements, like those in Hažín, Nižná Slaná, or Jánovce, are built entirely on the land of private, non-Roma owners.

Bardejov-Dlhá lúka and Rokytov are located on land owned by the municipality. Land in Uzovske Peklany is owned by a forest association, and in Nižný Tvarožec the owners of the land are unknown. All in all, the structure of ownership points to the very important role of municipalities and non-Roma owners in the land distribution and permits for settlements. It also points to the central role of municipalities in the process, for example, in the entitlements to the land of the unknown owners, or acting as the mediator between the interests of private owners and Roma communities.

The relationship between current entitlements and environmental quality is rather complicated. Although there is no clear pattern, there are certain tendencies here. For instance, the land in the most (environmentally) problematic areas tends to be owned by non-Roma private owners. In all seven cases where the situation in the Roma and non-Roma communities is evaluated as equal we find Roma settlements built on land owned by Roma and the municipality.

The first challenge in analysing entitlements is to determine their nature. As Sen [1981] notes, in many cases the appropriate characterisation of entitlements may pose problems, and in some cases they may well be best described as 'fuzzy' sets and related structures [Sen 1981: 48]. There are two factors that contribute to this 'fuzziness'. First, a substantial share of land belongs to 'unknown owners'. Eight Roma settlements are partly built on such land. This category represents a problem somewhat specific to Slovakia. The land is de jure private, but de facto it does not belong to any identifiable owner. This is no small problem.

\footnotetext{
${ }^{15}$ Land either bought by Roma or transferred to them by local municipalities. The latter approach is sometimes prompted by an effort on the part of local councils to abdicate responsibility for the area.
} 
This difficulty in determining ownership is mostly due to the chaos that ensued after 1945 and ignorance of the problem in the 1950s, when the collectivisation of agriculture, including agricultural land, began. ${ }^{16}$ In the late 1990s the state established a new land register, ${ }_{17}^{17}$ but progress has been slow, and in 2006 the Constitutional Court decided to prohibit any transfer of land from unknown owners to municipalities and the state. ${ }^{18}$

There are around 550000 hectares of land in Slovakia which on paper belong to private owners, but to which in reality property rights cannot be determined. ${ }^{19}$ In the two counties from which data were collected for this study, this applies to several thousand cases (459 006 unknown owners in Prešovský kraj, and 304815 in Košický kraj). ${ }^{20}$

Second, historically land was usually divided equally among heirs. ${ }^{21}$ Because of property and heritage laws, individual properties are often very small; the land is divided among dozens, or even hundreds of small owners. Tracing back the actual owner of the land under the Roma settlements is often very complicated. Even when it is possible, ownership may be divided among a number of people. This makes it difficult to sell or buy property, and in many parts of the countryside, private owners in practice are not interested in control and utilisation of their properties. They tolerate the Roma settlements because they do not have an alternative use. In economic terms the opportunity cost of not usuing the land under Roma houses is small or zero unless a new opportunity presents itself, such as the construction of a road or a tourist attraction, which would make even small pieces of land commercially attractive.

\section{Land, entitlements and control: 'not in my backyard'}

Entitlements—operationalised as land ownership and/or control—are studied here in the context of their development. Some settlements were built a long time ago, some during the former totalitarian regime, and others appeared recently, after the political changes in the 1990s. Although regimes have changed and the governance system has gone through rather different stages, there are similarities and deeper mechanisms in entitlement control.

${ }^{16}$ Very often only the name of the owner is listed in the land register but with no further identifying information or data.

${ }_{17}$ In Slovak, Register obnovenej evidencie pozemkov.

${ }_{18}$ Because of the land's commercial potential, there was and is a substantial lobby to shift this ownership so that the land can be utilised and/or privatised in the future.

${ }_{19}$ This is the latest publicly available government estimate dating from August 2006.

${ }_{20}$ The rather high number is due to the fact that the plots are often very small in size as the land is fragmented and divided up among heirs. See the following paragraph.

${ }^{21}$ In the Hungarian part of the former Austro-Hungarian Empire, all heirs obtained an equal share of an inheritance. This differed from the Austrian part, where agricultural land was usually inherited by the oldest son. 
Roma settlement in Slovakia has a long history. For instance, in 1661, the Town Council of Ružomberok allowed four Roma families to settle in the territory and produce lime for the city [Jurová 2000a, 2002b]. In the 17th and 18th centuries Roma were allowed to inhabit places allocated to them by the nobility, towns, and villages. During this period, pressure increased on the Roma to change their nomadic lifestyle and tie them to a particular location.

In the 20th century, and especially after the Second World War, municipalities (i.e. the non-Roma inhabitants of villages) began taking a greater role in selecting locations for Roma settlements. All the settlements described in this article were built before the Second World War or during the regime of centrally planned socialism. In the cases identified, people moved into a situation where environmental threats existed prior to their settling there. Roma houses are sometimes legal, but they are often illegal or do not comply with the building code and other relevant legislation.

Socialism and central planning added new dynamics and new trends to locating settlements. In the 1950s all Roma were forced to settle. A substantial part of the land was nationalised, entitlements came under the control of the ruling party, and it was the role of appointed local councils to govern. The councils usually tried to balance the general directives of the Communist Party and the interests of the local people (i.e. non-Roma) exercising control over the entitlement to the nationalised land in the possession of the state.

The traditionally larger size of Roma families, the collapse of socialism and central planning, and the economic and social transformation together led to a significant increase in the number of people living in the settlements. Roma who had been living in dormitories and houses for workers either lost their ability to pay their bills and were simply thrown out as soon as their employment contract terminated, or their dwellings were sold to private owners. Then they had no choice but to return to the shantytowns.

The social and economic transformation also brought back the central role of private ownership of agricultural land and forests (suppressed under socialism and collective ownership). Municipal councils and mayors are now directly elected and not appointed by the ruling party, but changes in entitlement control have only very recently become visible (as will be discussed below). Regardless of the regimes, from the very beginning of the settlements' history non-Roma (i.e. entitlement owners and controllers) have had a strong role in the allocation of places.

It is important to distinguish between ownership, control, and access [Bromley 1989; Devereux 2001]. While access is usually directly influenced by ownership or control, there may be control without ownership and ownership without control. Private ownership is of key importance, but what is also important is control of the entitlement over land that has unknown, scattered owners or is in the possession of the municipality or the state. In the present situation of mixed and unclear ownership of unknown entities, where known owners are not 
Figure 4. The different forces and actors that shape entitlements to land distribution in municipalities with Roma settlements

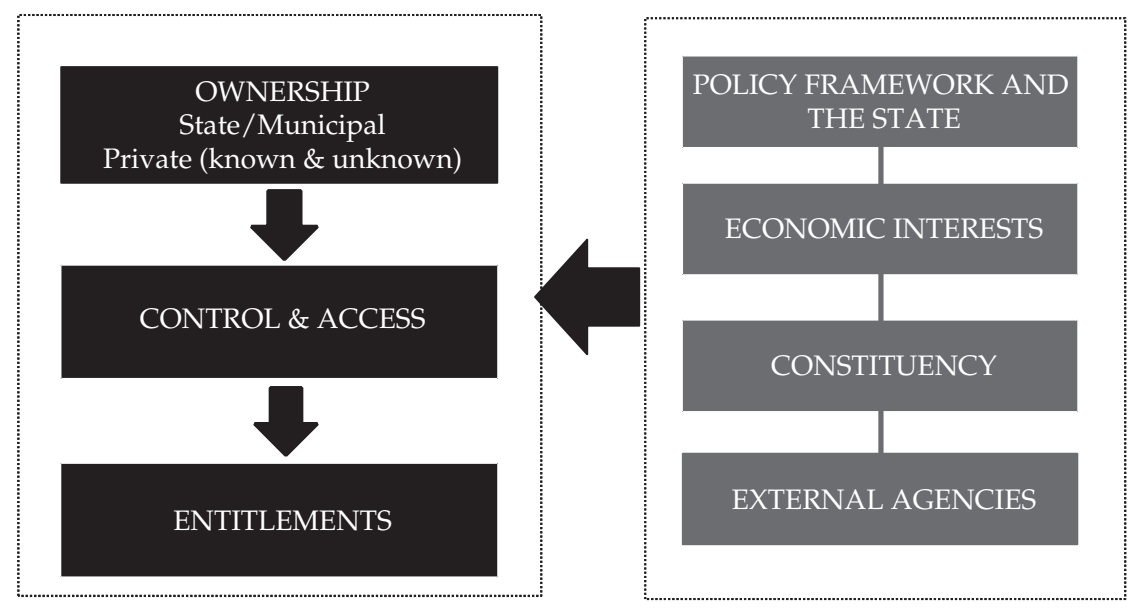

Source: The author.

particularly interested in their property (e.g. because of its low value, small size, fragmentation, or poor location), the role of the municipalities becomes central in land control and access guarantees.

As illustrated in Figure 4, entitlements to land in municipalities with Roma settlements are the rather complicated outcome of different forces and actors pursuing their own aims. There are multiple relationships among ownership, control or access, and entitlements, but we have to see them in the context of other factors that have an impact on the situation. It matters who the owner is, and it matters how control and access are managed in the framework of different political, social, and economic policies and interests.

The cases of environmental (in)justice identified in this research are to a substantial extent a result of local power struggles embedded in the overall framework of implemented (or, rather, not implemented) international and national policies and rules.

Entitlements to resources are subject to political, economic and social clashes within communities, and the stronger groups (whether in numbers or economically) may manipulate the distribution (or non-distribution) in their favour. As Amartya Sen pointed out [1984], limited access to environmentally safe land for settlement is the result of people generally not having access to land, rather than there not being enough suitable land. There are several strong factors that affect distribution that can be grouped and analysed as economic and social.

The first and most important factor is perhaps the economic one. The price of land or the value of real estate and its commercial potential influence deci- 
sions about where to settle or where to let newcomers to the village build their houses. Environmental conditions often have a significant impact on the value and commercial potential of land. There is not usually a strong economic interest in regularly flooded areas or contaminated sites, so the interest in the entitlement control is weak. On the other hand, entitlements to arable land, pastures, or productive forests have traditionally had a high value in rural communities, so there has been a stronger interest to control them.

An important economic trend, closely related to the overall development of local production and consumption patterns, is the shift in the demand for labour. This is especially true for low-skilled workers. Roma who traditionally worked as miners, lumberjacks, or seasonal workers on cooperative farms are no longer needed in the local economy. A decrease in agricultural production and mining, and new technologies and machines in agriculture and forestry have been gradually making unskilled labour redundant. These changes have also deeply affected non-Roma inhabitants of villages. As the Roma were among the first to lose their jobs (mostly due to the discrimination factor), the non-Roma focused on protecting the remaining work opportunities. The Roma thus lost one of the very few reasons for which they were tolerated by the majority. This is also expressed in spatial terms. This 'unwanted' minority is, through different mechanisms, gradually being forced to leave, moving further out to the outskirts of the cities or villages.

Social and especially ethnic prejudices and discrimination play an important role. In the cases studied it is common to find a spatial distance between the majority and the minority. Segregation tendencies lead to weaker ethnic or social groups becoming located in places allocated to them by those in control of entitlements to the land. The problem is that the land they are given, being commercially unattractive and as far as possible from the village, may also be land with comparatively worse conditions, resulting in environmental (in)justice.

This is something similar to the reaction to environmentally problematic activities expressed as the 'not in my backyard' syndrome (NIMBY). The term originally referred to the problems of environmental impacts from technological facilities, factories, or roads. The Roma are in this respect seen by the majority as a kind of 'social pollution', decreasing the well-being of those living in close proximity. ${ }^{22}$

The latest, and a very illustrative, example of where the NIMBY syndrome and entitlement control come together is the social housing projects supported by the EU and the national government as the most important measure to address the adverse situation of the Roma communities. Such housing projects developed in Slovakia (i.e. Sabinov, Letanovce, or Spišské Vlachy-Dobra Vôla) have one thing in common: new houses are planned (or already built) in places that are quite far from the villages.

${ }^{22}$ For instance, having Roma in the neighbourhood dramatically decreases real estate values. 


\section{Entitlements and environmental justice: trends}

As already mentioned, entitlements and entitlement-based control of resources is a dynamic process. The question that arises is how does this process influence the distribution of the environmental benefits and risks-i.e. environmental justice? There are several trends in entitlement distribution that are weakening or strengthening the Roma position. Among the most important weakening factors are: the changing value of the land; growing segregation tendencies; patterns of land ownership and concentration of property rights; improving law enforcement; and growing economic and social disparities. Among the strengthening factors we can list the role of the state and external agencies and the political mobilisation of the ethnic minority.

The value of land and its commercial potential has been changing over time. An agriculturally unattractive piece of land allocated to the Roma a century ago may turn out to be of good value decades later when real estate agents plan to build new housing or when a tourism industry develops. Two examples to illustrate this point are Letanovský Mlyn ${ }^{23}$ and Jánovce.

The Roma settlement in the part of a village called Letanovský Mlyn is located in a valley that leads into a national park. The mayor of the village has openly stated: ${ }^{4}$ 'As soon as we eliminate the former Roma settlement, we plan to build tourist facilities and parking lots in Letanovský mlyn.' In the eyes of non-Roma the location of the Roma settlement is one of the main obstacles to the development of the tourist industry in the village. In the spring of 2005 the municipality started to construct new public housing for the Roma in Letanovce. These new blocks of houses were to be located three kilometres outside the village. Furthermore, there was no direct road connecting this place with the village. ${ }^{25}$

Approximately 500 people are living in a Roma settlement in Jánovce with overcrowded houses and a single water pump serving the whole community. In 2011 the municipality launched an ambitious plan: the Roma settlement located in the village centre was to be moved approximately two kilometres outside the village (from the quarter Pod Machalovcom to Hlohy). The village mayor defended this decision on the grounds that the place where the current settlement is located belongs to private owners and the shantytown is built illegally and with-

\footnotetext{
${ }^{23}$ Although Letanovský Mlyn is not a part of the original research sample, it is situated in proximity to the other surveyed settlements and was visited and analysed during the field research. Social processes, conflicts, and trends not so clearly demonstrated in other places are apparent there.

24 'Letanovský mlyn stáahujú do novej osady.' (Letanovsky Mlyn Will Move to a New Settlement) SME, 28 April 2005. Retrieved 30 June 2011 (http://www.sme.sk/clanok. asp?cl=2028448).

25 As of March 2012 these houses are still not finished, owing to the lack of money allocated by Letanovce municipality and pressures from a neighbouring village. The houses are so far from Letanovce, that they are close to another, neighbouring non-Roma village.
} 
out permission. In his words: 'The settlement above the village centre depresses land prices, and the value of individual and municipal buildings and properties: we will get rid of illegal construction and the Roma will get new social housing.' The municipality defends its housing project with the claim that they do not have any other municipal land on which to construct social housing. The interest of private owners is clearly behind this move. They want to start housing construction in the village and for this they need to get rid of the Roma shantytown. With an estimated value of 3.3 million euros, this is a significant investment and the project is dependent on state funding. The Roma have signed agreements, despite the fact the village has not yet secured funds.

Both cases illustrate the ways in which the majority decides about minority settlement. The economic value of the land, commercial opportunities for land exploitation, and social factors all play a very important role. It is very probable that the current process reflects and replicates previous practice. It is just the economic drivers that are modified. Today it is not about arable land or pastures: the most valuable land nowadays is that which is suitable for building commercial houses or is situated on the edge of a national park where the ancestors of nonRoma in the village allowed Roma to settle decades ago.

Owners in Letanovce refused to sell land for the Roma housing project any closer to the village. In Jánovce we also find a tendency (besides commercial interests) to 'push' Roma further out of the village. These cases thus point to the problem of growing segregation tendencies, compounded by growing social inequalities, which at the local level results in the polarisation of the communities. In the end, new social housing may turn into ghettoes, with all their associated social and environmental problems.

Patterns of land ownership and the concentration of property rights further contribute to this polarisation. Development during the past two decades of reform has been strongly influenced on a national and local scale by the neoliberal development paradigm. This paradigm has been adopted at the central level and is promoted by business, the main think tanks, public intellectuals and the media. It is a paradigm of privatisation, deregulation and the transference of some control over the economy from the public to the private sector, reducing social welfare spending and where possible shifting welfare from public to private projects [Peet and Hartwick 1999; Garcia 2006; Hartwich 2009].

Adherence to this paradigm has given rise to several factors that impact the vulnerability (in one way or another) of marginalised people. The very first is the privatisation of state and municipal assets. Selling land, enterprises, or services has been a vital source of income. The transformation of the agricultural sector from cooperative and state-owned farms into private farms has gradually led to the sale of land to private owners. ${ }^{26} \mathrm{~A}$ side effect of this privatisation and transfer

${ }^{26}$ A side effect of this was that the collapse of entities that previously employed a substantial number of people with lower education caused mass structural unemployment. 
of ownership from public to private entities has been the concentration of ownership and stronger property rights regimes. This shift gradually enhances entitlement-based ownership and leads to improved law enforcement, as the new owners have more power and interests to control their properties. This is especially significant when the location of semi-legal or illegal settlements interferes with potential economic opportunities. It is very likely that we will see more and more forced evictions and resettlement of people in places where entitlements control is weaker (e.g. environmentally problematic areas).

It is important to see all these trends in the framework of the growing economic and social disparities and the mainstream public discourse in society. The problems of the poor or marginalised are increasingly framed as personal rather than systemic failures where structural causes are neglected..$^{27}$ There are enduring historical prejudices against the Roma, but the past 20 years of the transformation has heightened them significantly. Entitlements are used as tools for the further segregation of Roma communities and for moving them out of the space inhabited by non-Roma. There is pressure to re-allocate Roma to new places which is often accompanied by deepening segregation and potential for increasing inequalities in the access to environmental benefits or exposure to environmental risks.

At the same time we see see a counter-movement and new dynamics in entitlement distribution and control. The role of the state and external agencies and the political mobilisation of the Roma ethnic minority are enabling factors. The development policies of the EU provide somewhat limited support to counter the negative consequences of development by promoting economic and social cohesion goals. Yet without the EU effect it is difficult to imagine what the social cohesion policy in the country or in the region would be like. Besides pressure to comply with legal obligations, EU membership brings with it significant financial resources for adopting and implementing European policy goals. Two of them are particularly important: the concept of decentralisation (based on the EU subsidiarity principle), and the economic and social cohesion policies. The former led to rapid decentralisation, and the latter to an increase of economic transfers to marginalised regions in the EU together with national budgets (co-financing).

Decentralisation is usually promoted by different stakeholders (i.e. the EU, national governments, or NGOs) as a positive tool leading to empowerment, public accountability and transparency. In reality the situation is often more complicated, with mixed impacts on entitlement distribution and control. A combina-

\footnotetext{
Among them, the Roma ethnic minority was particularly hard hit due to discrimination in the job market [UNDP 2002; World Bank 2002, 2003; EC 2011].

${ }^{27}$ This is mainly due to the changes in overall production and consumption patterns reflected specifically in local economy transformation. Roma who were (to a varying degree) included in the local economies as seasonal labour, specialised craftsmen, or workers in factories or in services were no longer needed. Because of the discrimination in the labour market they were usually among the first to lose their jobs in rapidly downsizing enterprises.
} 
tion of privatisation, capital accumulation and the empowerment of local elites may lead to control over the opportunities that arise from decentralisation and in reality could add to the pressure towards the displacement and segregation of marginalised communities. This occurs especially in cases where mechanisms of local democratic participation are not respected or are applied in a very 'formal' way, resulting in a new choreography of elite power [Swyngedouw, Moulaert and Rodriguez 2002]. Or as Lane [2003: 283] puts it, in theoretical terms calls for the decentralisation of many areas of state responsibility and demands for an enhanced role for civic actors, particularly in the area of environmental management, fail to acknowledge the potential for powerful civic actors to subvert, rather than promote, democratic processes and outcomes.

It is precisely because of these dangers that the state and different agencies must actively step in. A ruling handed down by a court in Prešov on 17 June 2009 serves as an important precedent for many municipalities in Slovakia: the court decided that building social houses for Roma outside of the town territory in Sabinov was discriminatory and against the principles of social integration. The municipality and the Ministry of Construction and Regional Development lost the case and those affected have obtained compensation. Yet, the compensation will not solve their segregation problem and the cases identified in this (and other) research indicate that Sabinov is not an extreme example but a confirmation of adverse trends. The verdict is an important signal that Roma are entitled to nondiscriminatory practice in housing projects. It also points to the importance of civil society organisations, for initiating these kinds of court proceedings, and to the Roma themselves, who realised that there exist mechanisms to protect their rights.

Although there is a tendency among those subjected to harm to have little history of civic and political participation, we are seeing new trends. The most significant is perhaps the re-shaping of the meaning and possibilities of decentralisation. Despite the potential adverse effects on entitlement distribution described above, it also provides new opportunities. Decentralisation is a strong policy and institutional framework within which the Roma ethnic minority can unite, participate in the local elections, and change the status quo. There are approximately 320000 Roma living in 1575 identified settlements in Slovakia [OPSGRC 2005]. In the 1998 municipal elections 254 Roma candidates registered for local elections and out of them 56 were elected to councils. In the same elections 6 Roma mayoral candidates succeeded. In the latest 2010 election there were 330 Roma elected to municipal councils and 29 successful Roma mayors.

How will the role of the inter-ethnic relations, the influence of external agencies (i.e. the EU, the state or developmental NGOs), and the increasing civic and political participation of the Roma ethnic minority be reflect in entitlement distribution and control (and in addressing the problem of environmental (in)justice) is the subject of further research. 


\section{Conclusion}

As newcomers to villages with practically no resources to buy land, Roma were allowed to settle in places allocated first by the nobility, the gentry, farmers and later by the non-Roma majority and local municipalities. The location of the settlements is a result of complicated social processes shaped by social exclusion, ethnic discrimination, economic power and interests. Entitlements play a key role in decision-making at the local level, leading to cases of environmental (in)justice.

This research reveals that we need to go beyond the original formulation of entitlements built on legal ownership by individuals of alienable commodities. Weaker claims over resources, such as access and usufruct rights, as well as situations of uninterested or unknown owners strengthen the role of those who (through formal or informal authority) possess decision making power. It indicates that we need a more sophisticated understanding of entitlements, particularly in terms of how they relate to other concepts and how they are applied in context. Last but not least, we need external agencies (especially the state) to take an active role in promoting the entitlements of marginalised people and groups and in ensuring non-discriminatory practices.

The dynamics of the process and trends in entitlement distribution are important. This article showed how the changing social and economic context and shifts in land value influence entitlement distribution and environmental justice. The alarming trend seems to be the use of entitlements for further spatial segregation of the Roma and the building of new and extended barriers between the majority and minority population. At the same time, it is also possible to see examples of resistance and positive changes based on the re-formulation and reallocation of entitlements (e.g. in housing projects).

The results of the research suggest that we need to go beyond a simplistic descriptive understanding of entitlements. The way people and social groups approach the distribution of entitlements and how they control them depend on the broader context of economic and social interests and a deeper understanding of morals, values, and perceptions. The question is not just how to redistribute entitlements and address cases of environmental (in)justice. We have to see this also from the perspective of obligations and duties. In other words, those who control entitlements should also have the responsibility to use them for the sustainable management of natural resources while ensuring the non-discriminatory distribution of environmental benefits and risks.

RICHARD FILČÁK is a researcher at the Institute for Forecasting of the Slovak Academy of Sciences. His main research focuses on the poverty-environment nexus, on the coping strategies of people amidst global and local environmental and socio-economic changes, and on how social and territorial exclusion leads to exposure to environmental risks and vulnerability of people. His new book Living beyond the Pale: Environmental Justice and the Roma Minority will be published in 2012 by the CEU Press. 


\section{References}

Agyeman, Julian. 2002. 'Constructing Environmental Injustice: Transatlantic Tales.' Environmental Politics 3 (autumn): 31-53.

Antypas, Alexios, Richard Filčák and Tamara Steger. 2008. 'Linking Environmental Protection, Health, and Human Rights in the European Union: An Argument in Favour of Environmental Justice Policy.' Environmental Law and Management 20: 8-21.

Beck, Ulrich. 1999. World Risk Society. Cambridge: Polity Press.

Bowen, Willam M. and Michael V. Wells. 2002. 'The Politics and Reality of Environmental Justice: A History and Considerations for Public Administrators and Policy Makers.' Public Administration Review 6: 688-698.

Bromley, Daniel. 1989. 'Property Relations and Economic Development: The Other Land Reform.' World Development 17: 867-877.

Bryant, Bunyan and Paul Mohai. 1998. 'Is There a Race Effect on Concern for Environmental Quality?' Public Opinion Quarterly 62: 475-505.

Bullard, Robert D. 1990. Dumping in Dixie: Race, Class, and Environmental Quality. Boulder, CO: Westview Press.

Bullard, Robert D. and Glen S. Johnson. 2000. ‘Environmental Justice: Grassroots Activism and Impact on Public Policy Decision Making.' Journal of Social Issues 563: 555-578.

Chambers, Robert. 1994. 'The Origins and Practice of Participatory Rural Appraisal.' World Development 7: 953-969.

Cole, Luke W. and Sheila R. Foster. 2000. From the Ground Up: Environmental Racism and the Rise of the Environmental Justice Movement. New York: New York University Press.

Devereux, Stephen. 2001. 'Sen's Entitlement Approach: Critiques and CounterCritiques.' Oxford Development Studies 29 (3): 245-263.

Dunn, Tony. 1994. 'Rapid Rural Appraisal: A Description of the Methodology and Its Application in Teaching and Research at Charles Stuart University.' Rural Society 4 (3/4): 332-342.

Elliot, M., R. Lowe and P. Kleindorfer. 2004. 'Environmental Justice.' Journal of Epidemiology and Community Health 58: 24-30.

Elvers, Horst-Dietrich, Mathias Gross and Harald Heinrichs. 2008. 'The Diversity of Environmental Justice.' European Societies 10 (5): 835-856.

Environmental Protection Agency (EPA). 1996. Draft Environmental Justice Strategy. Washington, DC: Environmental Protection Agency.

European Commission (EC). 2011. Communication from the Commission to the European Parliament, the Council, the European Economic and Social Committee and the Committee of the Regions: An EU Framework for National Roma Integration Strategies up to 2020. Brussels: European Commission.

Filčák, Richard. 2010. 'Migration to Contaminated Sites: Migrants' Settlements in Central and Eastern Europe Built in Places with High Environmental and Social Vulnerability.' Pp. 133-145 in Environment, Forced Migration and Social Vulnerability, edited by Tarik Afifi and Jill Jäger. Berlin: Springer-Verlag.

Filčák, Richard. 2012. Living beyond the Pale: Environmental Justice and the Roma Minority. Budapest and New York: CEU Press (in print).

Filčák, Richard and Daniel Škobla. 2011. 'Unequal Access to Natural Resources. Understanding Solidarity and Ethnicity in Slovakia.' Pp. 227-251 in Re-inventing Social Solidarity across Europe, edited by Marion Ellisson. Bristol: Policy Press.

Garcia, Marisol. 2006. 'Citizenship Practices and Urban Governance in European Cities.' Urban Studies (43): 745-765. 
Guy, Will. 2001. Between Past and Future: Roma of Central and Eastern Europe. Hatfield: University of Hertforshire Press.

Harper, Krista, Tamara Steger and Richard Filčák. 2009. ‘Environmental Justice and Roma Communities in Central and Eastern Europe.' Environmental Policy and Governance 19: 251-268.

Hartwich, Mark O. 2009. 'Neoliberalism: The Genesis of a Political Swearword.' CIS Occasional Paper 114. St Leonards: Centre for Independent Studies (CIS).

Hurrle, Jakub. 2005. 'The Third World in the First World. Development and Renewal Strategies for Rural Roma Ghettos in Slovakia.' Pp. 141-163 in Spatial Planning and Urban Development in the Ten New EU Member States, edited by Uwe Altrock, Simon Güntner, Sandra Huning and Deike Peters. Aldershot: Ashgate.

Jurová, Anna. 2002a. 'Rómovia v období od roku 1945 po november 1989.' (Roma in the Period between 1945 and November 1989) Pp. 53-77 in Čačipen Pal o Roma: A Global report on Roma in Slovakia, edited by Michal Vašečka. Bratislava: IVO.

Jurová, Anna. 2002b. 'Historický vývoj rómskych osád na Slovensku a problematika vlastníckych vztáahov k pôde-nelegálne osady.' (The Historical Development of Roma Settlements in Slovakia and the Problem of Property Rights to the Land-Illegal Settlements) Paper presented at the conference ‘Bývanie Rómov a rómske osadyriešenie sociálnej exkluzie', 6-9 June, Prešov, Slovak Republic. Retrieved 1 September 2011 (http://www.saske.sk/cas/archiv/4-2002/Jurová-st.html).

Kurian, Priya A. 2000. 'Generating Power: Gender, Ethnicity and Empowerment in India's Narmada Valley.' Ethnic and Racial Studies 23 (5): 824-856.

Lane, Markus B. 2003. 'Decentralization or Privatization of Environmental Governance? Forest Conflict and Bioregional Assessment in Australia.' Journal of Rural Studies (19): 283-294.

Leach, Melissa, Robin Mearns and Ian Scoones. 1997. 'Environmental Entitlements: A Framework for Understanding the Institutional Dynamics of Environmental Change. Discussion Paper 359. Brighton: Institute of Development Studies.

Leach, Melissa, Robin Mearns and Ian Scoones. 1999. 'Environmental Entitlements: Dynamics and Institutions in Community-Based Natural Resource Management.' World Development 27 (2): 225-247.

Mann, Arne. 1992. Neznámi Rómovia. (The Unknown Roma) Bratislava: Ister Science Press.

Matlovič, Rene. 2005. Geografia obyvatel' stva Slovenska so zretelom na rómsku Minoritu. (Geography of the Inhabitants of Slovakia with a Focus on the Roma Minority) Prešov: Prešovská univerzita.

Peet, Richard and Elaine Hartwick. 1999. Theories of Development. New York: Guilford Press.'

Pellow, David. 2002. Garbage Wars: The Struggle for Environmental Justice in Chicago. Cambridge, MA: MIT Press.

Pellow, David, Tamara Steger and Rebecca McLain. 2005. Proceedings from the Transatlantic Initiative to Promote Environmental Justice Workshop, 27-30 October, Budapest, Hungary. Retrieved 3 May 2012 (http://www.cepl.ceu.hu/system/files/Final\%20Report\%20on $\% 20$ the $\% 20$ Transatlantic $\% 20$ Initiative $\% 20$ to $\% 20$ Promote $\% 20$ Environmental $\% 20 J u s t i c$ e\%20Workshop.pdf).

Office of the Plenipotentiary of the Slovak Government for Roma Communities (OPSGRC). 2005. Atlas Romskych komunit na Slovensku 2004. (The Atlas of Roma Communities of Slovakia 2004) Bratislava: The Office of the Plenipotentiary of the Slovak Government for Roma Communities.

Scandrett, Eurig. 2000. 'Community Work, Sustainable Development and Environmental Justice.' Scottish Journal of Community Work and Development 6 (spring): 49-58. 
Scheffel, David Z. 2005. Svinia in Black and White: Slovak Roma and Their Neighbours. Peterborough, ONT: Broadview Press.

Schlosberg, David. 1999. Environmental Justice and the New Pluralism: The Challenge of Difference for Environmentalism. Oxford: Oxford University Press.

Schlosberg, David. 2004. 'Preconceiving Environmental Justice: Global Movements and Political Theories.' Environmental Politics 13 (autumn): 517-540.

Sen, Amartya. 1981. Poverty and Famines: An Essay on Entitlement and Deprivation. Oxford: Clarendon Press.

Sen, Amartya. 1984. Resources, Values and Development. Oxford: Basil Blackwell.

Sen, Amartya. 1999. Inequalities Reexamined. Oxford: Oxford University Press.

Shelton, Dinah. 1999. 'Environmental Justice in the Postmodern World.' Pp. 21-30 in Environmental Justice and Market Mechanisms: Key Challenges for Environmental Law and Policy, edited by Klaus Bosselmann and Benjamin Richardson. London: Kluwer Law International.

Smith, Mark J. and Piya Pangsapa. 2008. Environment and Citizenship: Integrating Justice, Responsibility and Civic Engagement. London: Zed Books.

Steger, Tamara and Richard Filčák. 2008. 'Articulating the Basis for Promoting Environmental Justice in Central and Eastern Europe.' Environmental Justice (1) 1: 49-53.

Steger, Tamara, Alexios Antypas, Lucie Atkins, Fiona Borthwick, Claude Cahn, Richard Filčák, Krista Harper, Ivona Malbasic and Katarina Medarova. 2007. Making the Case for Environmental Justice in Central \& Eastern Europe. Budapest: CEU Center for Environmental Policy and Law and the Health and Environment Alliance.

Stephens, Carolyn, Simon Bullock and Alister Scott. 2001. 'Environmental JusticeRights and Means to a Healthy Environment for All.' Special Briefing No. 7. London: Friends of the Earth.

Swyngedouw, Erik, Frank Moulaert and Arantxa Rodriguez. 2002. 'Neoliberal Urbanization in Europe: Large-Scale Urban Development Projects and the New Urban Policy.' Antipode 34 (3): 547-582.

United Nations Development Programme (UNDP). 2002. The Roma in Central and Eastern Europe-Avoiding the Dependency Trap, a Regional Human Development Report. Bratislava: United Nations Development Programme.

United Church of Christ Commission for Racial Justice (UCCCRJ). 1991. The Proceedings to the First National People of Color Environmental Leadership Summit, 24-27 October, Washington, DC. Retrieved 3 May 2012 (http://ecojustice.net/document/principles. htm).

Walker, Gordon, Jon Fairburn, Graham Smith and Gordon Mitchell. 2003. Environmental Quality and Social Deprivation. Bristol: Environment Agency.

World Bank. 2002. Poverty and Welfare of Roma in the Slovak Republic. Bratislava: World Bank.

World Bank. 2003. Roma in Expanding Europe—Breaking the Poverty Gap. Washington, DC: World Bank. 